\title{
Bardowie rezydenci . Fenomen poety dworskiego w świetle pamiętników ze wschodnich kresów Rzeczypospolitej I polowy XIX wieku
}

Dorota Samborska-Kukuć 


\section{Dorota Samborska-Kukuć}

\section{Bardowie rezydenci. Fenomen poety dworskiego w świetle pamiętników ze wschodnich kresów Rzeczypospolitej I połowy XIX wieku}

Q pecyficzną, niepoważnie w sensie politycznym i spolecznym traktowaną grupą szlachec-

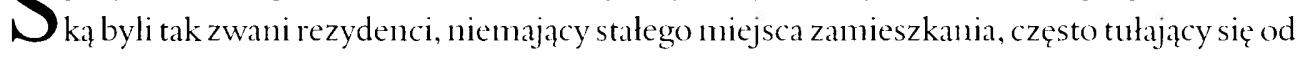
dworu do dworu w poszukiwaniu chlebodawców, mający różne zawody, najczęściej jednak próżnujący. Losem takich ludzi stało się przesiedlenie w głąb Rosji lub wcielenie do wojskal. Bardzo niepochlebnie wyrażał się o nieosiadlej, drobnej szlachcie pewien gubernator podolski, dowodząc konieczności przesiedlania przez rząd rosyjski Polaków z terenów zabranych:

Trzecią liczbę klasy szlachty tworzą ludzie niemający ani osiadłości, ani stałego przytukku, przechodzący z jednego miejsca na drugie, od obywatela do obywatela, z guberni do guberni, niemający przyczyn cokolwiek cenić, niemający nic do stracenia, niewolnicy tego, kto ich żywi, odziewa i laskami obdarza, i dlatego gotowi na każdy krok przeciwko sumieniu i uczciwości, (...) pracownicy i słudzy podczas powstania, ludzie niebezpieczni i mogacy być szkodliwymi w każdym nieprzewidzianym wypadkı. Wyprowadzenie ich z tego kraju byłoby użytecznym pod każdym względem, ale są oni na usługach obywateli za umową i bez umowy; rzadko który z nich żonaty, rzadko który zna i ma gospodarstwo,

\footnotetext{
1 Ukazani z 7 marca i 3 kwicmia 1797 roku car Pawell polecil wstrzymać przesiedlanic szlachty polskicj, natomiast próżnujących i zbicdnialych szlachciców kazal umicścić jako podoficerów w wojskach liniowych. Zob. H. Mościcki, Pol bert'm aróle', Warszawa 1924, s. 27.
} 
nawykli do wiçkszych lub mniejszych wygód życia dworskiego, rozproszeni, oddaleni od rodziców i krewnych ${ }^{2}$.

Wnosząc z powyższej wypowiedzi, ludzie prowadzący taki tryb życia postrzegani byli przez rosyjską elitę rządzącą jako margines społeczny, który wyznaczają ,jednostki zdeklasowane, nie mające określonego społecznego statusu, (...) uważane za zbędne i za takie uważające się" ${ }^{3}$. W sytuacji, w jakiej znalazły się wschodnie tereny byłej Rzeczypospolitej na przełomie wieków XVIII i XIX. nietrudno było spaść ze szczebli drabiny społecznej na sam dól i nawet z dnia na dzień znaleźć się na marginesie. Toteż ci, których okrutny lub ironiczny los pozbawił możliwości samostanowienia i zmusil do czepiania się łaskawych pańskich klamek, pochodzili z różnych pięter szlacheckiego gmachu' ${ }^{+}$.

Rezydenci, poszukujący przytulnego kąta w bogatych domach magnackich lub szlacheckich, wywodzili się najczęściej z najuboższej szlachty; bywało, że ich deklasacja stanowila wynik utraty majątku w okolicznościach nie zawsze niezależnych od włáciciela, że powodem pauperyzacji było utracjuszostwo, rozwiązły tryb życia, rozmiłowanie w grach hazardowych, słabość do trunku, wreszcie lenistwo czy inercja duchowa. Ponadto, cieszący się w dawniejszych czasach niezmierną popularnością zawód dworaka ${ }^{5}$ był wciąż najlepszym pomysłem na

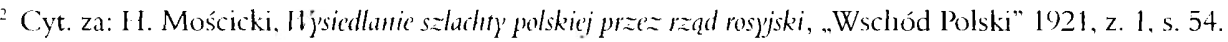

'S. Czarnowski. Ludzic zbędni u'stuzbie pratmocy. w: idem, Dzicha, t. 2. Warszawa 1956, s. 186-187. Por. S. Grodziski, Ludzie luźni. Studium z historii paristu'a i pran'a polskiego, Kraków 1961, s. 49-51; T. Veblen, Teoria klasy' pró̇inacoj, tl. J. i K. Zagórscy. Warszawa 1971, s. 40.

+ Golota, która zostala przymuszona do podjęcia pracy, najczęściej znajdowala ją w administracji dworskiej i folwarcznej. .. Niewielki nawet folwark zatrudnial calą machinç administracyjną: rządç̨, ckonoma, karbowego. gumicnnych, rękodajnych. Na micjscach tych najchçtnicj widziana byla szlachta jako elennent pewny, związany wspólnym pochodzeniem stanowym. Stanowiska tc byly niéźle platne, a szczególnic wysokie zarobki otrzymywat ekonom (...). Zajęcia te zapewnialy mozliwość spokojnego życia. a nawet dorobienia siç majatkı. Od kandydata przyjnowanego do adninistracji folwarcznej nic wyınagano specjahnego wyksztalcenia, natomiast wyższe zadania stawiano przy przyjmowaniu na dwór magnacki” (A. Stroynowski, Poz)'cja spoteczna

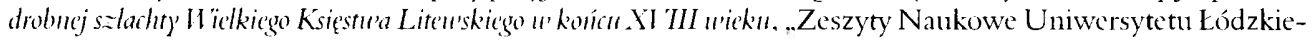
go", Nauki Humanistyczno-Spolecznc, 1976, z. 4, s. 102). Zajęcia ckonoma były wyraźnic okseślone, wymagania sformulowanc. Zob. Instrukcje dla ekonoma "d dobrach Tomasza L'miaston'skiego na Biafornsi (po 1812 r.), w :

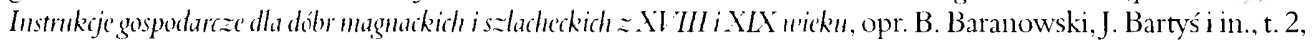
Wroclaw 1958 . s. 251-263.

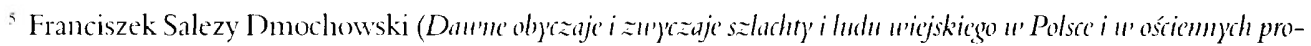
wircjach. Warszawa 1860. s. 161-162) dokonuje rysu historycznego tradycji zdobywania „profesji” dworzanina: ..Dwory byly najwyższą dla modzicży szkolą. Po skończeniu nauk modzian dla ostatecznego poloru i wprawy do stuzby cywilnej lub wojskowej oddawany byl przez ojca lub krewnych do jakicgo dworm. Tam zamiłował religiç, patrząc, jak ją szanowali najznakomitsi w kraju mçzowic, jak święcie dopełniali jej przepisy, a z obowiązku razén z państwem będąc na wszelkich nabożéstwach rannych, na mszy i pacicrzach wieczornych, ciągle widząc skromność prawdziwą. pobożność wyższych, przywykal i sam do nicj glęboko, i na caly wick w umysl ja wpajal. Stat siç moralnym, imnych bowiem przed sobą nie mial wzorów, tylko staropolskie cnoty (...). Dobrym nauczył siç być obywatelem, przysłuchując siç poważnym radnych panów rozmowom (...). Tu siç oswajal młodzicniec z dawnymi kraju swego i innyclı państw dzicjani, poznawal obecny stan rzeczy i ksztalt rządu (...)". Nic brak w opisic Dmochowskicgo i krytyki obyczajowości dworskicj. Po śmierci Stefana Batorego następuje wedlug autora powolny upadek moralności, bo „po dworach niknçly starożytıe cnoty, zamiłowanie ogólnego dobra kraju, tworzyly się stronnictwa, i dworzanin (...) dziclił zatargi ınożnych, niccue zlych, błçdne cnotliwych nawet (...) zle dochodzilo inn dalcj, tyn wyższego stopnia, często więc słusz- 
życie. W zapiskach pochodzącej z powiatı słıckiego Ewy Felińskiej, która wspomina wybór curriculum vitae swego ojca, Zygmunta Wendorffa (pokolenie urodzone w latach széśćdziesiątych XVIII wieku), czytamy:

W owej epoce były tylko dwa zawody dla młodej szlachty potrzebującej pokierować się w świecie, opierając siç na zdolnościach osobistych: dwory magnatów i palestra. Do dworów pańskich wchodzili zwykle synowie obywatelscy; byla to niejako szkoła przygotowująca do życia obywatelskicgo, albo też młodzież obdarzona śmiałością, zręcznością i pewnyın usposobieniem zaręczającym późniejsze powodzenie. Komu brakło tych warunków, wolał iść do palestry i tam pracą i nauką zdobywać późniejsze stanowisko. Służba dworska, mieszcząc pod protektoratem możnego pana, bez wytkniętych wyraźnie obowiązków, bez ścislej służbistości, byla ponętniejsza dla mlodzieży zroslej swobodnie, lubiącej zwykle okazałość, zabawy i życie ruchliwe, do którego się przystępowało bez wielkiej mozoły. Byle trochę śmiałości, trochę sprytu, na czym nie zbywało młodzieży polskiej, i trochę giętkości w charakterze, do czego usposabialo wcześnie domowe wychowanie, mające na celı dalszą karierę modzieńca, tworzyło się stanowisko wygodne, uwieńczone w konícu (...) wczasem i dostatkiem; panowie bowiem nigdy nie opuszczali w starości tych, co życie cale trzymając się ich klamki, nie zrobili sobie żadnego funduszu, takim wioska jaka dożywociem zwykle zabezpieczała schylek dni od nędzy. Jednak nie wszyscy dworsko zaczynający zawód potrzebowali tej pomocy od mecenasów. Synowie obywatelscy, wyksztatciwszy się na dworach i porobiwszy znajomości, wchodzili później w życie obywatelskie, żenili się, byli urzędnikami, zawsze jednak zostawał międ zy opiekunem a klientem rodzaj życzliwości wzajemnej, który to związek rozciągat się na całe życie".

Taką służbę dworską wspomina z rozrzewnieniem i namaszczeniem Seweryn Soplica, parnawski cześnik:

Stużba po pańskich dworach szlachcicowi krzywdy nie robiła: pan był panem, ale razem opiekunem shıgi, i jeżeli jak ojciec karat, jak ojciec kierowat i o losie pamiętał. Ale nie każdemu dostać się do pańskiego dworu!! Trzeba było mieć za-

ne są na dwory skargi, jako to w przyslowiı: "Cnota i pokora nic ma miejsca u dwora". Za Augustów dwory skazily siç calkowicie, juz do nicl przystosować można (...). że to zçborwoly, okolcki. lekoroby, krążýswiaty. biegusy, pasibrzuchy, darmojady, piccuchy, bałanuty, świcrzopki i świegoty. którym język jak na kołowrocic bicga. starzypiçthi. którzy pólmiski u dworu oblizując i rozmowom pań u dworu przysluchując siç, różnymi wiadomościani jçzyk sobic pomazali, i tym pomiçdzy czcladzią szcrmują i prostych manką swą omamiają.

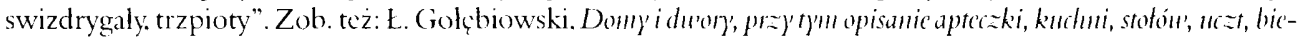

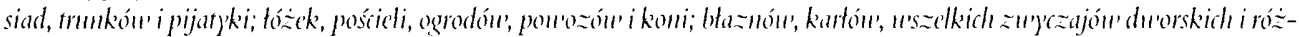

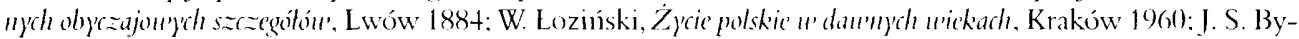

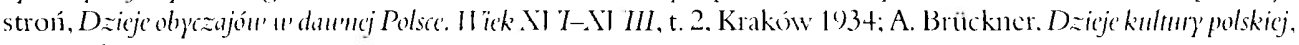
t. 3, Kraków 1931.

E. Feliníska. Pamiętniki ż́zia, t. 1, Wilno 1856, s. 19-20. 
sługi ojca lub krewnych za sobą albo jakich dobrodziejów, co by się chicieli wstawić $(\ldots)^{7}$.

Magnaci chętnie przyjnowali pod swój dach tych, którzy mogli służyć im jako zausznicy; przestała obowiązywać tradycyjna zasada, że „dwór stanowil pole do poloru i umysłowego wykształcenia calej generacji szlacheckiej, (...) był szrankami tylko, gdzie zwabioną trzymali panowie (...) drużynę swoich popleczników"». Opinia publiczna zazwyczaj postrzegala przyjaźń między bogatym magnatem a ubogim szlachcicem jako z gruntu fałszywą i podejrzaną. We wspomnieniach Bartłomieja Michałowskiego czytamy o smutnym przewidywaniu losów szlachetki, który zaufał możnemu panu. Zgodnie z ówczesną mentalnością krzywo patrzano na biednego rezydenta, widziano go bądź jako naiwnego, bądź „napiętnowanego jakąś podłością"). Ale i ta, w ostateczności korzystna materialnie, sytuacja uległa radykalnej zmianie, gdy szlachta przestala być potrzebna magnatom jako polityczne wsparcie na sejmach i sejmikach. Status totumfackich zdewaluowal czas, a „panowie zmienili dawny obyczaj. Z trudnością wciśnie się gdzie biedny szlachcic" 11) — jako żałosną znajduje swoją sytuację materialną i towarzyska jeden z bohaterów Pana Jana ze Śıisłocz)', reprezentant licznej już wówczas zbiedniałej szlachty, marzącej o jakimkolwiek zajęciu przy dworze.

Wnikliwą charakterystykę z elementami klasyfikacji fenomenu rezydentury " przeprowadza na przykładzie przyjaciela swojego dziadka Ignacy Chodźko we wspomnieniach litewskich:

[Ludzie ci należeli] do licznego jeszcze natenczas, a dziś wygasłego zupelnie bractwa rezydentów i dworaków, rozsypanych gęsto po kraju (...) wchodzących w skład niejednej szlacheckiej ziemi i niejednego obrazu tantoczesnych domowych obyczajów (...). Dzielili się rezydenci stosownie do wewnętrznego swego powołania i posiadanych talentów (...). Każdy z nich, posiadając wszelkie doskonałości swojej profesji, miał jeszcze, jak to wyżej namienitem, reguly i zasady, jakby dawnych rycerskich zakonów, całej kongregacji wspólne, to jest: ochotę do nieustamnej whóczęgi, póki zdrowie i własne lub darowanego konika nogi służyly; nienawiść do ciąglego zajęcia się i pracy; na koniec większy lub mniejszy pociąg do Aquae'vity'. Wdowcy bezdzietni lub starzy kawalerowie, nie micli oni pospolicie żadnych ścisłych związków ani obowiązków. Każdy dom szlachecki był dla nich familijnym, bo wszędzie chleb powszedni i kąt opiekuńczy z ochotą dla nich otwarty znajdowali. Owszem,

${ }^{7}$ H. Rzcwuski. Pamiatki Soplicy. Warszawa 1978, s. 69.

${ }^{8}$ K. W. Wójcicki, Obrazy'starodau'ne, t. 2, Warszawa 18+3. s. 246.

"H. Rzewuski, Pamiq̨miki Bartomicja . Michatouskiegu, t. 1, Petersburg 1856-1857. s. 136-137.

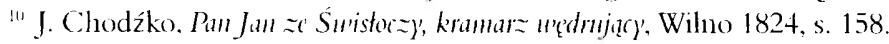

"Typologia rezydentów jest. z uwagi na rozmaitość podcjmowanych przez nich dzialań, bogata, ijak się wydaje, ciaggle otwarta. Nic funkcjonije wlaściwie nazwa. która bylaby adekwatna do statusu przemieszczającego siç od dworu do dworu ..dorożkarza”, szukającego dachu nad glową w zamian za uatrakcyjnianic czasu dykteryjkami, facecjami i imnymi ..lekkościami” pióra. Spośród cickawszych tego typu osobliwości literackich wymicnić wypada Feliksa Boznańskiego, działającego w okolicach Lwowa. 
w czasach, gdy każdy gospodarz, pilnując wlasnej grzędy, niewicle zewnętrznych miał stosunków i związków, zbieracz taki i rozwoźca nowin, wiadomostek, anegdot, dykteryjek, przybywający z życzliwym sercem i z wesolym humorem do domu, zawsze pożądanym byl gościem, i zaraz poufalym stawal się domownikiem. Wreszcie przywiązanie szczere do familii, około których się żywili, i poczciwość prosta, nieinteresowna, zalecala ich wszystkich. Niewiele żądali, bo wszystkie ich konieczne potrzeby życia, bez pracy i kosztu, bez próśb nawet, ludzkość i dobrotliwość staroświecka ojców naszych opatrywala. Wszakże w przypadkach tyczących się ich szczególıych talentów i profesji dozwalali oni sobie niekiedy malych wyboczeń od ściśle sumiemnej ścieżki. (...) główne dzialy rezydentów, dałyby się (..) na kilka poddziałków rozgalęzić: ogrodników, lekarzy (..), a nawet poetów! Ale dość i tej krótkiej wzmianki i opisu, abyśmy przypomnieli sobie lıdzi żyjących bez troski, a przed którymi troski ucickały z domów; spomiędzy których niejeden z nas mial piastuna dni dziecinnych, a mentora i najzyczliwszego domownika w modzieńczym wieku; którzy na koniec niknęli spośród nas jak usychające jedne po drugich drzewa w ogrodach, którym ziemia pożywczych soków odmawia! ${ }^{12}$.

Funkcjonowanie rezydentury jako zjawiska społecznego jest wedhug Józefa 1 Dunina Karwickiego przykladem patriarchatu,

...dowodem wielkiej ofiarności, wielkiego miłosierdzia chrześcijańskiego (...) przodków, którzy w złej czy dobrej woli gotowi byli ostatnim kęsem chleba podzielić się z bratem szlachcicem, nie czekając, aby ten wskutek niesprzyjających okoliczności doszedł do nędzy i zmuszony był wyciągać rękę po jałmużnę"13.

Rezydent był przyjacielem pana domu, posiadał często parę koni, kilka klaczy, a nawet przynoszącą mu osobisty zysk pasiekę. W zamian za opiekę rezydent bawił gości rozmową, czytał swemu panu ksiązki i gazety, towarzyszył w polowaniach, przejażdzkach, przechadzkach, grzybobraniach, modlitwie, był partnerem do gry w warcaby lub karty.

Ci, najczęściej bezżenni kawalerowie lub wdowcy, wykolejeni społecznie i majątkowo, starali się na miarę swych umiejętności być w różny sposób użyteczni:

...ten z lekka dozorowat przy gospodarstwie rolnym, ów psy legawe lıb jamniki układał do polowania, uczyl śpiewania kanarków przy pozytywce lub sztucznego gwizdania kosów, nastawial sidła na ptaszki, pułapki na myszy lub trutki na szczury, rozcieral tabakę dla państwa, (...) pędził różne wódki na alembiku itp., itp. ${ }^{1+}$

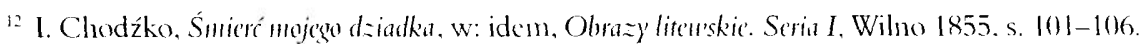

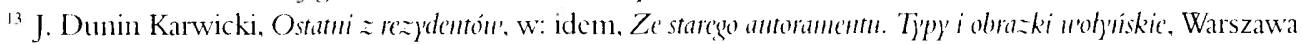
1899, s. 129-1.30.

it Ibidem, s. 132-133. 
Najbardziej ceniony byl „rezydent z tęgą głową do kielicha (...). Szeroko o nim opowiadano i zazdroszczono go innym dworom ${ }^{15}$.

Wśród rezydentów pierwsze skrzypce grali poeci ${ }^{16}$. Mieszkali w zamkach bogatych magnatów i w dworkach szlacheckich. Najczęściej umieszczano ich w skrzydłach dworu lub na jego pięterku ${ }^{17}$. O wejściu pod protektorat mogły decydować rozmaite okoliczności; nie zawsze byla to droga tak tradycyjna jak ta, którą wkroczyli na dwór Czartoryskich Franciszek Karpiński czy Franciszek Dionizy Kniaźnin. W opowiadaniach Pawla Zawiszy czytamy o wzięciu na dwór śpiewaka z ludu, który zadziwil i wzruszył swego przyszłego pana. Ten dał biedakowi wykształcenie i wprowadzil do towarzystwa, które obcowanie z nim poczytywało sobie za zaszczyt ${ }^{18}$.

Szeroko rozpowszechniona gościna była starym zwyczajem odziedziczonym po czasach mecenatu. Roman Kaleta, komentując zjawisko mecenatu, wpływającego zasadniczo na rozwój ,najprzedniejszej literatury okresu”, zauważa także jego mankamenty: poniżanie się, a nawet upodlenie poszukujących zarobku artystów. Mecenat bowiem, przed ukonstytuowaniem się instytucji shuzących ludziom pióra, stanowił jedyną formę finansowego wsparcia dla twórców zunuszonych żyć ze swojego talentu" ${ }^{10}$. Protektorat

...rzadko bywal bezinteresowny, mecenas bowiem zwykle stosowal zasadę „to ut des" (daję, byś dawal) i stawial poecie różne wymagania. Do najpospolitszych należało żądanie pochwal, zasłuzonych i niezasłużonych, przy czym w razie braku zalet i zasług pochwaly zastępowano pochlebstwamin".

Tak pisano panegiryki lub dımki i ballady, by zadośćuczynić swemu chlebodawcy ${ }^{21}$.

„Bardowie rezydenci”, jak nazywa poetów i grafonanów zamieszkujących na dworach możnych Julian Tuwim, byli najczęściej ludźmi w jakiś sposób upośledzonymi, jeśli nie w sensie majątkowym, to dosłownie; cierpieli z powodu kalectwa, ale potrafili z niego uczynić sedno „artystycznych” dzialań i groteskowe narzędzie swojego fachu. Ci

...ostatni Mohikanie blazeńskiego cechu to (...) rozmaite, dziwaczne, wykolejone egzystencje, co za laskawy chleb zabawiały swych żywicieli gawędą i żartem, piosnką i facecją, zdolıością do kielicha i fenomenalnym apetytem, a nieraz samym pokracznym wyglądem ${ }^{22}$.

15. Ibidem. s. 134.

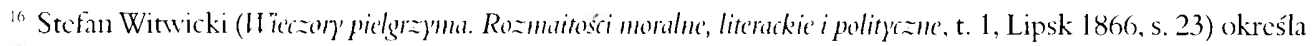
fenomen „poctów ustnych“ jako jedną z polskich osobliwości. stanowiących o odrębności obyczaju.

17 Zob. J. Obst, Nasze du'or' wiejskie'. Wilno 1911. s. 118 (odbitka z ..Kwartalnika Litewskiego”).

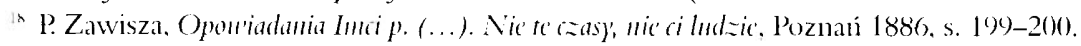

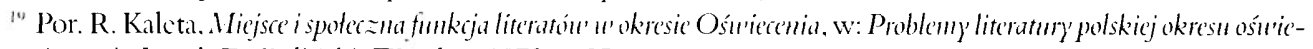
conia, seria I, red. Z. Goliński, Wroclaw 1973. s. 25.

2" J. Krzyżanowski. Sztuka stowa. Rzecz o zjawiskach literackich. Warszawa 1984. s. 12-13.

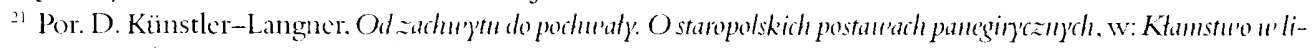
teraturze, red. Z. Wójcicka, P. Urbański. Kielce 1996, s. 20-31.

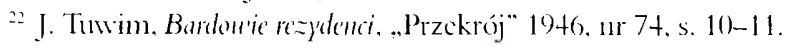


Na dowód istnienia hudzi podobnego autoramentu przywołuje Tuwim fragmenty barwnych życiorysów: Tomasza I Iussarzewskiego, Józefa I Iohola, Benedykta I lulewicza i Adama Wąsowicza. Najoryginalniejszy z tego kwartetu rezydentów Hohol, mieszkający na dworze wojewody kijowskiego Franciszka Salezego Potockiego, doczekal się nawet należnego mu miejsca w satyrycznych Mieszaninad ol yczajon'?' ' Jarosza Bejły, gdzie został odmalowany jako skończony alkoholik i włóczęga, stały bywalec najpodlejszych wiejskich karczm, w przerwie pijackich peregrynacji bajkami i dumkami umilający czas swojemu chlebodawcy ${ }^{23}$. Podstawową rolą rezydenta-literata było więc ubarwione opisywanie życia dworskiego, wychwalanie gospodarza i rozpraszanie jego smutków.

Franciszek Morawski w przypisie do tragmentu Du'orca mojego dziadka kreśli z kolei portrecik objazdowego, niemalze profesjonalnego mistrza dykteryjek i anegdot, wodzireja co przedniejszych imprez lokalnych, mającego za cel rozweselanie odwiedzanych przez sicbie domów. Domokrążca ten,

...obrawszy sobie kilkanaście domów, objezdżał je i po kwartale lub dłıżej w nich przebywał. Byl to zwykle ubogi szlachcic, a całym jego majątkiem bryka i para koni wypasionych po dworach. Powolaniem jego było mieć w zapasie na czas swego pobytu mnóstwo żarcików, anegdot, politycznych nowinek, zdarzeń okolicznych, waśni familijnych, projcktów do małżeństw; słowem, ciągle dom rozweselać. Starał się on dla większej wziętości za każdym powrotem do tegoż samego domu z nowym zapasem zartów i anegdot przybywać. On to wszystkie kuligi układał i na nich prowadzit. Zabitym był patriotą, wielce nabożnym i nie ostatnim do kicliclıa ${ }^{24}$.

O wierszopisach-rezydentach z terenu Inflant pisze Kazimierz Bujnicki:

...oprócz kapeli i teatrów, ku zabawie państwa i gości mialy domy bogate wierszopisów zwanych poetami, a z których dowcipniejsi odgrywali razem rolę trefnisiów, bez ujmy wszakże klejnotowi szlachectwa. Byli to bowiem bene nati, ale ubodzy, rezydenci przypuszczeni do stolu pańskiego (rozumie się na szarym konícu); zadaniem ich bylo pisać wierszowane imita Minerna, powinszowania i śpiewy, zwane kantami, na obchody uroczyste, tudzież rymowane facecyjki godowe, na zawołanie w czasie obiadu, a deklamowane z pewnym natężeniem. ażeby je brano za improwizacje. Im mnicj było w tych wierszach sensu, tym większą w słuchaczach wzbudzaly wesołość, tym gęściej sypały się oklaski dla poety, sypiącego wiersze jak z rękawa. Improwizatorowie ci nie doznawali nigdy od nikogo upokorzenia; śmiano się z iclı rymów, ale w sposób nie obrażający, owszem, zachęcający. Nie dawano im za napój wina z wodą, ani wieńczo-

${ }^{23}$ H. Rzcwuski, Micszaniny obyragjou'e, t. 1, Wilno 18+1, s. 254.

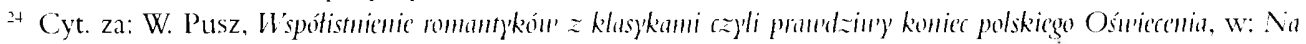

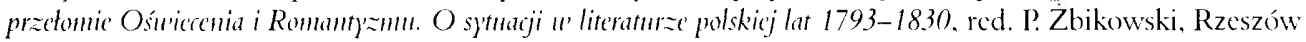
1999. s. 49. 
no liśćmi kapusty (...), ale im nalewano wina czystego i nieskąpo, dla dodania weny. Stąd zaden z nich nie zadal sobie śmierci z rozpaczy, lecz dokonywal szczęśliwie żywota w domu swego benefaktora. Poeta domowy, na podobieństwo średniowiecznych bardów i minezengerów, opiewał splendory domu swego mecenasa, slawę przodków, rodowód bogaty w parantelę świętą itd. mato się troszcząc o ścisłą historyczną w panegirykach prawdę; było to dozwolone poeticae licentiae ${ }^{25}$.

Nieopodal Inflant, po tej samej stronie Dźwiny, w Justynianowie, znajdował się piękny dwór Justyniana Niemirowicza-Szczytta, pisarza Wielkiego Księstwa Litewskiego. Gospodarz był animatorem życia kulturalnego północnej części Białorusi ${ }^{26}$. W pamiętniku jego syna Józefa Szczytta czytamy:

Śmialo mogę powiedzieć, że nie było w tej stronie wówczas świetniejszego donu nad dom ojca mego (...). Łączył on ze starodawną skromnością obyczaje nowego wieku, gustowność życia, upodobanie w literaturze i manierę, nawiedzany był przez najpoważniejsze osoby, a zawsze tak gośćmi napetniony, że nigdy mniej nie siadało osób do pierwszego stołu niż trzydzieści, w marszałkowskim dwadzieścia i tyleż w szafarskim. Liczba osób domowych wynosiła do dwóchset ${ }^{27}$.

Podobny opis tego dworı znajdıjemy we wspomnieniach wnuczki Justyniana, Elżbiety Pakoszowej z Rudominów:

Stół w Justynianowie nie był wystawny, ale porządny i obfity. Stół był długi, gdyż (...) domowników i rezydentów zawsze tam dużo się znajdowało, co Justynianów za własny dom uważając, tak wygodnie, jakby u siebie tam gościli. (...). Dom (...) na sposób staropolski urządzony, niż przepychem ścian i mebli więcej przytułkiem dla tylu biednych ozdobny, zawsze był zapełniony zbiegowiskiem krewnych, którzy w osobie jego pana, a dziada mego, jakby patriarchę swego widzieć byli radzi, blogosławieństwa jego pragnąc, thumnie się tam zbierali ${ }^{2 x}$.

Charakterystyczny i pelen szacunku jest utrzymany w panegirycznym tonie opis uroczystości imienin sędziwego już wówczas Justyniana:

Dzień imienin zacnego starca obchodzony gromadnie (...) a sam on piękny, czerstwy, rumiany, bogato po polsku przybrany, zdobny orderami, przedstawiał obraz dygnitarza kraju (...), wszystkich zarówno ściskal (...) tych starców rezy-

\footnotetext{
K. Bujnicki, Lpodobanie " niespodziankath. .Kronika Rodzinna" 1869, s. 27.

26. O historii dworu rodziny Nicmirowiczów Szczyttów traktuje R. Aftanazy. Dzicje rezydenci ma daumych kresarh Rzezz'pospolitej, t. 1. Wroclaw 199+. s. 239-2+1.

${ }^{27}$ J. Szczytt. Lłamck z pamiçtmikóm. .. Kronika Rodzimma” 1884, s. 5-9, 35-39, 73-76, 107-112.

ix E. z Rudominów Pakoszowa. Pamiçmik. .Kronika Rodzima” 1881, s. 278.
} 
dentów, co jego chlebem wiek caly się żywili, innej stużby prócz różańca nie znając. I nie tylko dla tych postrojonych juz w żupany i kontusze rezydentów swoich znajdował słowa życzliwości, idąc do kaplicy rozmawiał nieraz z uboższą szlachtą (...), życzliwym udarowal slowem. (...). A i w kaplicy pięknie było patrzeć na starca otoczonego wierną sobie drużyną, co złamanym już głosem pomagał dworni swojej śpiewać pieśni, hymny i psalmy własnego układu, i nawet wydrukowane po wielu domach takie zdarzało się widywać książeczki, i to wierszem pisane ${ }^{2 !}$.

Z gościny Justyniana Szczytta korzystał Jan Onoszko, wskazany przez Szczytta juniora jako szlachcic-rezydent. Tam zapewne powstala spori część jego opublikowanego po śmierci dorobku" ${ }^{311}$.

Biczem ironii chłoszcze poetów-rezydentów Antoni Edward Odyniec, nazywając ich „muchami”, od których musi opędzać się Pegaz. Nie mają oni ambicji bycia głośnymi, to znaczy drukowanymi, w odróżnieniu od ich gatunkowych powinowatych, czyli „bąków”, których celem było zaistnienie na szerszym forum czytelniczym. Wspomina Odyniec o ich sporej liczebności na Litwie, nazywa maniakami i próżniakani

...włóczącymi się ze swymi wierszami jak dziady z ewangeliczką (tylko że nie piechotą), po szlacheckich dworkach na wsi i wyzyskującymi (...) gościnność i upodobanie $w$ wierszach gospodarzy ${ }^{31}$.

Bard tego rodzaju, jak pisze Odyniec, mając na myśli Jana Szurłowskiego, bez żadnego pomysłu na życie, wykształcony o tyle, o ile,

...powożąc się sam w kalamaszce, z psem zazwyczaj zamiast konia, jechał od bramy do bramy, rzekomo jakby w gościnę, a w gruncie rzeczy po jałmużnę w ksztalcie ofiary dla poezji $\mathrm{i}^{32}$.

Anemiczna artystycznie twórczość poetów mimorum gentium żyjących na łasce pańskiej zalewala prowincjonalne dwory ${ }^{33}$, bywała śpiewana przy akompanianencie jakiegoś instrumentu muzycznego jako miłosne wyznanie lub rubaszua piosenka przy kielichu. Mania wierszoklectwa w początkach XIX wieku miala swoje źródło w sposobie uczenia w szkolach zakonnych.

\footnotetext{
29) Ibidem, s. 473 .

31) O życiu i twórczości J. Onoszki. sentymentalisty-rezydenta, zob. D. Samborska-Kukuć. Kim byt Jan Ono-

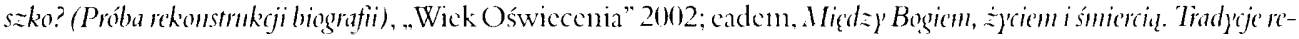

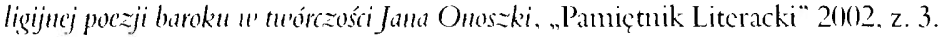

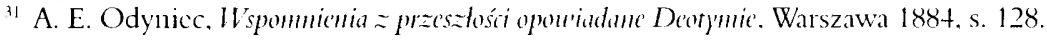

32 Ibidenll.

33 T. S. Grabowski (Z pogramiza polsko-biatormskiego. w: Kriega pamiątoma ku czi Stamistan'a Pigonia. Kraków 1961, s. 45) podaje nastçpujące prowincjonalnc dworki jako nicjsca gościnnic przyjunujące rezydentów-poctów: Stary Konstantynów, lanów, Cybulów, Nikopol, Olawa, Krożça. Cudnów, Mosarz. Poczanowska Góra, Harodek Grodzicki.
} 
Śmialo można by twierdzić, że nie było szkoly, która by nie wydała jakiego laureata. Tylko że jak ochota do pisania wierszy nie zawsze łączyć się zwykła $z$ ochotą do nauki i pracy, tak też i większa połowa tych samorodnych synów Apollina usypiała na wiek na swych laurach szkolnych, lub (...) słynęla jeszcze czas jakiś w granicach swego powiatı (... $)^{3+}$.

Szczególnym powodzeniem cieszyła się konwencja sentymentalna, poetyka à la Karpiński, nadająca się do wyrażania rozmaitych stanów emocjonalnych, właściwych życiu towarzyskiemu prowincji. Swobodne rozumienie poglądów estetyczno-literackich twórcy Laury i Filona, stanowiących opozycję wobec klasycyzmu, spowodowalo zjawisko masowości rymowania bez względı na talent czy estetyczne predyspozycje literackie autora:

...uznano, iz każdy, kto ma czule serce, może pisać, przedmiotem zaś poezji stać się ma świat zwykłych, prostych, codziennych uczuć i spraw. W ten sposób tradycja sentymentalizmu przejawiała swą wyłączną aktualność dla całego zastępu domorosłych poetów, motywujących uprawianie skonwencjonalizowanego piśmiennictwa wygodną formą czulości, która miała zastąpić zarówno głębszą refleksję nad współczesną sytuacją literacką, jak i rzetelny wysiłek w budowaniu wypowiedzi poetyckiej ${ }^{35}$.

Tematyka tej bezprzykladnie plodnej i rozległej, najczęściej graniczącej z grafomaństwem działalności twórczej poetów nadwornych oscylıje albo wokół sytuacji miłosnych: powrotów, rozstań, przekomarzań, flirtów, wspommień et cetera, albo pochwał życia wiejskiego z całyn urokiem prostego bytowania w cnocie, blogosławionym ubóstwie i miłości bliźniego, albo też kreacji młodych patriotów wyruszających na bój po czułym pożegnaniu z kochanką. Funkcjonalnym gatunkiem okazala się tu siclanka, bo jej konwencjonalny kostium pasterski oddziaływał komunikatywną lekkością na wyobraźnię odbiorcy, nastawioną na rozrywkę.

Utwór, który spodobal się czytelnikom, krążyl ze dworu do dworu, odczytywano go na zebraniach sąsiedzkich, przepisywano, powtarzano z pamięci; zdarzato się, że i autor, który poezje swe drukiem wydał, większą popularność uzyskał przez odpisywanie po dworach i dworkach poszczególnych utworów, aniżeli przez lekturę drukowanych tomów ${ }^{30}$ -

- pisal Jan Stanislaw Bystron. Wpisywano krążące wiersze w domowe silvae rérum, notowano na luźnych kartkach, zapełniano wolne miejsca w kalendarzach. Twórczość taka trafiała na podatny grunt, królıjąc $w$ dworkach prowincji, nastawionych na sentymentalną piosenkę z akompaniamentem gitary lub klawikordu, gdzie karierę zrobiły już utwory Karpińskiego, Ludwika Kropińskiego, Wincentego Reklewskiego oraz braci Kazimierza i Andrzeja Brodziń-

\footnotetext{
34 A. E. Odyniec. op. cit., s. 106.

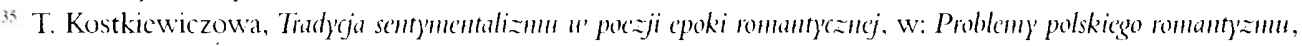
seria III, red. M. Żmigrodzka, Wroclaw 1981, s. 151.

36. J. S. Bystroń, op. cit., t. 1. s. 41\%.
} 
skich $^{37}$. Zadowalające powszechny gust dziecko muzy sentymentalnej szczebiotało zarówno we dworze, jak i pod strzechą, a osiągając nieporównaną popularność, zaczynalo żyć wlasnym życiem, osierocone przez autora i pozbawione rodowodu, niczyje, bo adoptowane przez wszystkich — śpiewających i słuchających, wędrujące między dworem i chałupą, gdzie „służąca pokojowa podsłuchuje, co śpiewa jej panienka, uczy się, potem przechwala przed swyni wioskowymi rówieśnicami, te znowu, nie chcąc ustąpić dworskiej modzie, uczą się od niej jak mogą, i po niejakim czasie piosnka wchodzi w użycie" ${ }^{34}$ i rozsławia jej autora. Ten zaś, choć spragniony aplauzu, ,zaplacić musiał (...) za rozgłos tę najwyższą lichwiarską cenę, która zowie się bezimiennością" ${ }^{3 !}$. Warto dodać, iz zatarty rodowód takiego utworu, stworzonego najczęściej przez szlachcica-ziemianina, czasem nawet przez poetę-profesjonalistę, sprzyjał anektowaniu takiej piosenki, ballady czy dumy przez lud, traktıjący ją jak swoją własność (taki byl na przyklad los Lan'y i Filona) ${ }^{+1 !}$.

Niezwyczajna zatem mnogość poetyckich wystapień bardów rezydentów dowodzi nie tylko określonych gustów i upodobań literackich potencjalnych czytelników, którymi byli najczęściej okoliczni mieszkańcy rodzinnej prowincji „wieszcza”+1. Świadczy również o „horacjanizmie" twórcy, spragnionego sławy, usilującego za wszelką cenę zaistnieć na szerszym forum czytelniczym, i ilustruje „czarujący egotyzm (...) artysty, który stara się (...) umknąć z szerokiego cienia, jaki w końcu na wszystkie książki rzuca historia”+2.

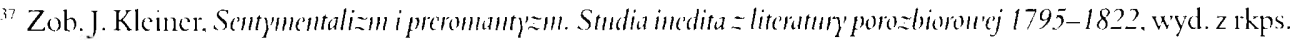
i opr. J. Starnawski, Kraków 1975. s. 93-99.

${ }^{3 *}$ Waclaw [Szymanowski], Jeszcze kilka stón o guberni miniskicj, , Tygodnik Ilustrowany” 1869, nr 8+-85, s. 77.

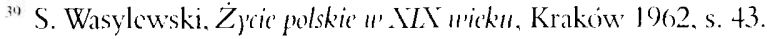

"t" Adaun Mickicwicz, chcąc sprawdzić wiarygodnośc folklorystycznych badań Jana Czeczota. postal mu Kinrhanek Maryli opatrzony falszywą notą: ,myśl ze śpicwu litcwskicgo”. Najbardzicj zagorzaly folklorysta nic rozpoznal falsyfikatu. Dowicdziono, żc zanierzona bądź przypadkowa symulacja autentyku może z powodzcnicm go imitować. Por. B. Dopart. Micki'uiczon'ski romantyzm przedlistopadou'y. Kraków 1992. s. 63. Zob. tcż

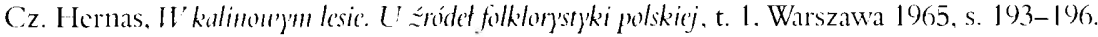

"I O nomenklaturze aktywności pisarskicj w czasic przckonu romantycznego zob. J. Kanionkowa. Żýcie literackic u' Polsce u' picru'szcj poton'ic XIX wicku. Studia, Warszawa 1970, s. 275-276.

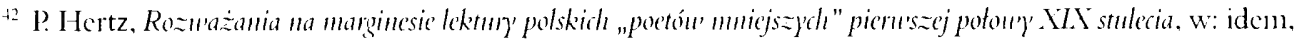
Domena polska, Warszawa 1961, s. 51. 